POLICE MATTERS 



\section{Police Matters}

The Everyday State and Caste Politics

in South India, 1900-1975

20

Radha Kumar

CORNELL UNIVERSITY PRESS

ITHACA AND LONDON 


\section{Copyright (C) 202I by Cornell University}

The text of this book is licensed under a Creative Commons Attribution-NonCommercial-NoDerivatives 4.0 International License: https://creativecommons.org/licenses/by-nc-nd/4.o/. To use this book, or parts of this book, in any way not covered by the license, please contact Cornell University Press, Sage

House, 5I2 East State Street, Ithaca, New York I4850.

Visit our website at cornellpress.cornell.edu.

First published 202I by Cornell University Press

Library of Congress Cataloging-in-Publication Data

Names: Kumar, Radha, I98I- author.

Title: Police matters: the everyday state and caste politics in south India, 1900-I975 / by Radha Kumar.

Description: Ithaca [New York]: Cornell University Press, [202I] | Includes bibliographical references and index.

Identifiers: LCCN 2021005664 (print) | LCCN 2021005665 (ebook) | ISBN 978I50I76I065 (paperback) | ISBN 978I50I760860 (pdf) | ISBN 978I50I760877 (epub)

Subjects: LCSH: Police_-India_-Tamil Nadu_History—2oth century. | Law enforcement-India_-Tamil Nadu_History—2oth century. | CastePolitical aspects - India-Tamil Nadu-History. | Police-community relations-India_-Tamil Nadu_-History—2oth century. | Caste-based discrimination-India-Tamil Nadu-History-2oth century.

Classification: LCC HV8249.T3 K86 202I (print) | LCC HV8249.T3 (ebook) | DDC 363.20954/820904-dc23

LC record available at https://lccn.loc.gov/202I005664

LC ebook record available at https://lccn.loc.gov/202I005665

Cover image: The Car en Route, Srivilliputtur, c. I935.

(C) The British Library Board, Carleston Collection: Album of Snapshot Views in South India, Photo 628/I (40). 


\section{S $\mid \mathrm{H}$ The Sustainable History Monograph Pilot \\ $\mathrm{M} / \mathrm{P}$ Opening up the Past, Publishing for the Future}

This book is published as part of the Sustainable History Monograph Pilot. With the generous support of the Andrew W. Mellon Foundation, the Pilot uses cuttingedge publishing technology to produce open access digital editions of high-quality, peer-reviewed monographs from leading university presses. Free digital editions can be downloaded from: Books at JSTOR, EBSCO, Internet Archive, OAPEN, Project MUSE, and many other open repositories.

While the digital edition is free to download, read, and share, the book is under copyright and covered by the following Creative Commons License: BY-NC-ND 4.0. Please consult www.creativecommons.org if you have questions about your rights to reuse the material in this book.

When you cite the book, please include the following URL for its Digital Object Identifier (DOI): https://doi.org/I0.7298/j2j5-ya4I

We are eager to learn more about how you discovered this title and how you are using it. We hope you will spend a few minutes answering a couple of questions at this url: https://www.longleafservices.org/shmp-survey/

More information about the Sustainable History Monograph Pilot can be found at https://www.longleafservices.org. 
